\title{
Drawing on experience
}

Stephen Hancocks OBE
Editor-in-Chief

The BDJ Upfront section includes editorials, letters, news, book reviews and interviews. Please direct your correspondence to the News Editor,

Kate Quinlan at k.quinlan@nature.com. Press releases or articles may be edited, and should include a colour photograph if possible.

$\mathrm{E}$ ven if I say so myself, I am not a bad hand at painting - but mainly walls, ceilings and window frames. I'm not good at drawing. I know that because I was told so by Mr Atkinson our art teacher when I was 12 years old. The homework was to draw a clothes peg and I diligently got out a ruler and pencil, measured and scaled up the said laundry apparatus, and created what I thought was a rather splendid representation. No. This was not a drawing. Fail.

To me, it was what was asked for: my interpretation of the object in question. Top marks went to a fussy pastel version in unrealistic colours with an impressionistic pile of washing in the background.

Hurumph. Years later, I was encouraged again to draw and without the threat of $\mathrm{Mr}$ Atkinson leering over my shoulder. Here, I was told that there was no right or wrong; it was about what I felt and how I wanted to express it. I didn't draw a clothes peg but I think I did a better job and actually rather enjoyed it. It felt liberating and ever since I have been less hard on myself.

As you may have observed, our current cover series is drawn (pun intended) from art works created by dentists, DCPs and dental students during the pandemic and through various lockdowns, quarantines and isolations. Our art editor has deftly 'set' them in different room or space locations to add to the effect of them being 'art works' for the benefit of the framing of the cover, but they are each an expression of the creator. A brief description of each is given in the relevant journal and an overview is provided by Rachel Jackson who inspired the series. ${ }^{1}$ Please follow the series and you will discover a wealth of fascinating inspirations and circumstances from the 12 people who have been brave enough to allow us to publish their work.

The pandemic is responsible for many things, including a torrent of clichés.
Unfortunately, it is difficult to avoid some of them and two that I am about to use are that nothing will ever be quite the same again, and that we really don't know with much certainty where we are all going - which, if not true before most of us had ever heard of Wuhan, certainly are definite facts of life now. What will happen to NHS dentistry? Has the caries rate risen? Are more people really seeking cosmetic solutions than previously? Will the lack of hands-on clinical teaching be detrimental to future graduates? I don't know; you don't know; no one knows.

What we do all know, however, is how we would like it to be. What is it that we want? This often sounds as if it is a question to what happens. Or it could be a paintbrush and canvas, a camera, a lump of clay and sculpting tools. What matters is not the form of expression but the expression itself. You don't have to be 'good' at it, you don't have to show it to anyone and you don't (most of all) have to be embarrassed about it. But I think if you are bold enough to try it, you will be surprised by the results. It calls to mind an anecdote once told to me. In a seminar, a presenter had asked the participants to write down a list of items all beginning with 'I want...' which he then used with them during the session. Some years later, he was approached by one of those who had attended. 'I want to thank you', said the dentist, 'you asked us to write a

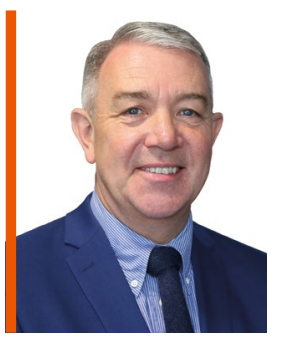

'Perhaps now is a time above all others for thinking about what we want, or would like, or would wish to happen' tease out a selfish answer. Expressing what we want can make us sound like a spoilt toddler or an avaricious consumer but it need not. Perhaps now is a time above all others for thinking about what we want, or would like, or would wish to happen. To attempt to formulate ways forward which may be personal or professional, intimate or open, specific or general. The traumas that we have variously been through in the last 18 months have given us much food for thought - working from home more; working in different roles; seeing patients in another light.

OK, so where am I going with this? I'm suggesting that you pick up a pencil and paper, and start drawing or writing what you feel from your experience and see list of wants and although I hadn't realised it until you presented that opportunity, what I wanted was a divorce'. The presenter related that he didn't know what was coming next. 'Well, I got it and I am now happier than I have ever been before'.

I am not, emphatically not, attempting to lead readers into partnership disharmony, but I am suggesting that you draw on your experience and take some time to actively reflect on what you would like to happen next. Honestly, I think it will do us all good.

\section{References \\ 1. Quinlan K. Rachel Jackson: 'There is no more poignant time to consider art as therapy'. Br Dent J 2020; 228: 498-501.}

https://doi.org10.1038/s41415-021-3372-6 